\title{
COMMUNITY EMPOWERMENT TOWARDS GREEN SETTLEMENT IN RT.03 / RW.01 PETUKANGAN UTARA VILLAGE, PESANGGRAHAN SUB-DISTRICT, SOUTH JAKARTA
}

\author{
Anggraeni Dyah and Harfa Iskandaria \\ Universitas Budi Luhur, Indonesia. \\ anggraeni.dyah@budiluhur.ac.id
}

\begin{abstract}
Dense settlements in urban areas are one of the problems in DKI Jakarta, due to the discrepancy between the area of land and the population. RT.03/RW.01 Petukangan Utara Village Pesanggrahan Sub-district South Jakarta is one of the densest settlements in DKI Jakarta which is located next to Universitas Budi Luhur. Based on SNI 031733-2004, the population density level in RT.03/RW.01 of North Petukangan Village, Pesanggrahan Subdistrict, South Jakarta is included in the category of High Density. This can be seen in the dense residential row with the lack of Green Area. The community develops houses by using the land for building and pavement. This impacts the lack of healthy air circulation by SNI-14-1993-03 about the thermal comfort area of buildings for Indonesians. With thermal comfort that is not by SNI standards, the Community Service activity was made by the Universitas Budi Luhur Architecture Department to increase public knowledge about thermal comfort in homes with limited land. Thermal comfort can be achieved by creating a vertical garden on less land to produce cool air in residences. The activity uses the method of community empowerment so that the community can independently create a vertical garden in their homes and know its benefits as thermal comfort in the building. The results of the activities of the Community Empowerment Towards a Green Settlement on RT.03/RW.01 North Petukangan Village Pesanggrahan sub-district of South Jakarta is such settlements have a vertical garden as a natural air conditioning system. With the vertical garden as a natural air conditioning system, it can reduce the use of energy for artificial air conditioning, so that it saves energy and produces better air quality.
\end{abstract}

Keywords: Community Empowerment, Dense Population Settlements, Natural Air Conditioning, Thermal Comfort, Vertical Gardens

\section{INTRODUCTION}

The rate of population increase increases the need for settlements in urban areas, while the area of land in urban areas does not increase. The speed of population growth should be balanced with the speed of providing residential facilities. In the end, densely populated settlements emerge with increasing population. Various problems in densely populated settlements arise due to the lack of supporting facilities and infrastructure. Also, densely populated settlements often cause environmental problems and reduce the quality of life (Pourpeikari Haris, 2017).

One of the densely populated settlements in DKI Jakarta that are close to the location of Budi Luhur University is RT.03 / RW.01 Petukangan Utara Village, Pesanggrahan District, South Jakarta. This area is categorized as included in densely populated settlements due to the density of residents and the density of buildings in the settlement (Anggraeni Dyah, 2018).

One characteristic of densely populated settlements is the limited land in each residence. The area of residential land is maximized for buildings, not infrequently violations of the availability of Green Open Space occur in almost all residences. The loss of green open space has an impact on the loss of water infiltration which can cause flooding, as well as the loss of greening that serves as a buffer against urban air pollution. Dense population settlements become part of neighborhoods that are not environmentally friendly in urban areas (Ragheb et al., 2016).

Environmentally friendly settlements are green or sustainable concept settlements. Environmentally friendly settlements are steps to respond to environmental problems in densely populated settlements found in urban areas. The design of environmentally friendly settlements or green settlements is settlements with a green environment (there are protective vegetation, boundaries, creepers and ground cover). Zero waste settlement does not produce waste that pollutes the environment, so it must have waste management and water management system independently. Physically the building and environment must also pay attention to the rules of a healthy home, healthy environment, save energy and use renewable building materials (Husein abbualrejal, 2017).

Thus the Architecture Study Program of Budi Luhur University will hold a community empowerment program RT.01 / RW.01 Petukangan Utara Village, Pesanggrahan District, South Jakarta through Community Service activities entitled "Community Empowerment Towards Green Settlements". In this activity, the community will be given the knowledge to provide vertical greening on limited land. Vertical greening functions as a natural air 
conditioner in buildings, so it can save energy use for artificial air conditioning. In the end, the community environment RT.03 / RW.01 is expected to become an environmentally friendly settlement in DKI Jakarta (Anggraeni Dyah, 2017).

\section{METHOD IF IMPLEMENTATION}

To directly engage the community in the effort to implement Community Empowerment Towards Green Settlement activities in RT.03 / RW.01 Petukangan Utara Village, Pesanggrahan Subdistrict, South Jakarta, an approach process with the TRI-DAYA concept is needed.

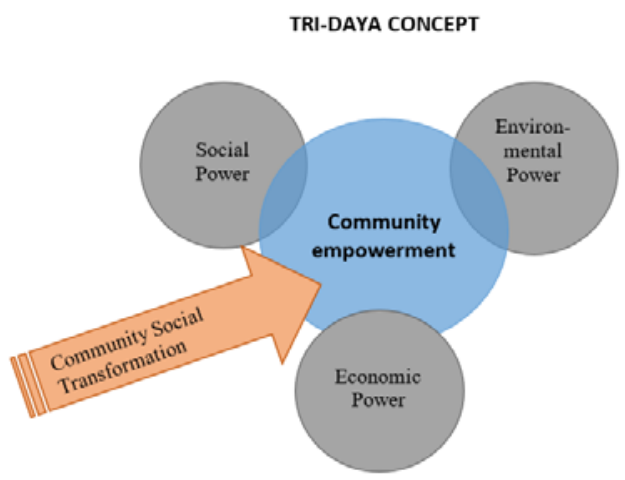

Picture 1. Chart of the Concept of Community Empowerment Towards Green Settlements in RT.03 / RW.01

\section{Social Power}

The concept of Social Power is applied by empowering the community towards environmentally friendly through increased knowledge about the benefits of greening as natural air conditioning in homes.

\section{Environmental Power}

The concept of Environmental Power is applied by empowering communities to create environmentally friendly settlements through vertical greening on limited land and greening using pots from reusable materials.

\section{Economic Power}

The concept of Economic Power is applied by empowering the community to make vertical greening as natural air conditioning in their respective homes, to save costs for the use of energy for artificial air conditioning.

\section{OBJECTIVE SOCIETY}

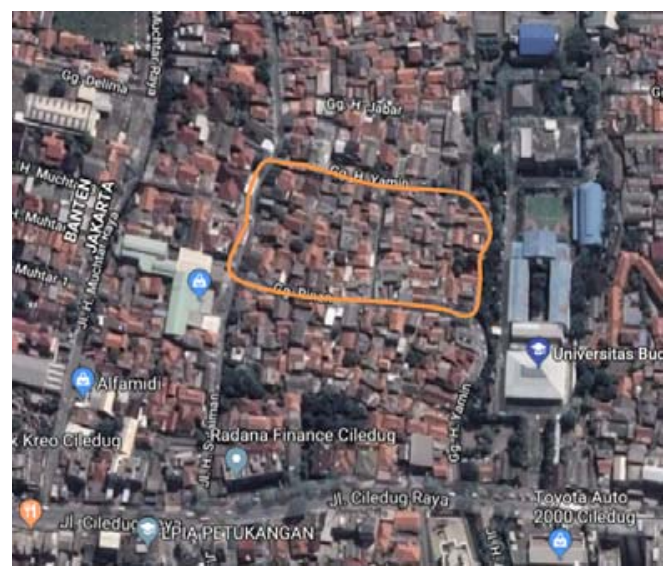

Picture 2. Regional Boundaries RT.03 / RW.01

The total area of RT.03 / RW.01 of North Petukangan Village, Pesanggrahan Subdistrict, South Jakarta is \pm 1 Ha with a total of 120 residential buildings. The population is 300 people with 120 families. Regional boundaries are as follows:
North : RT.04/RW.01
East : Pesanggrahan River
South : RT.01/RW.01
West : Sulaiman Street 


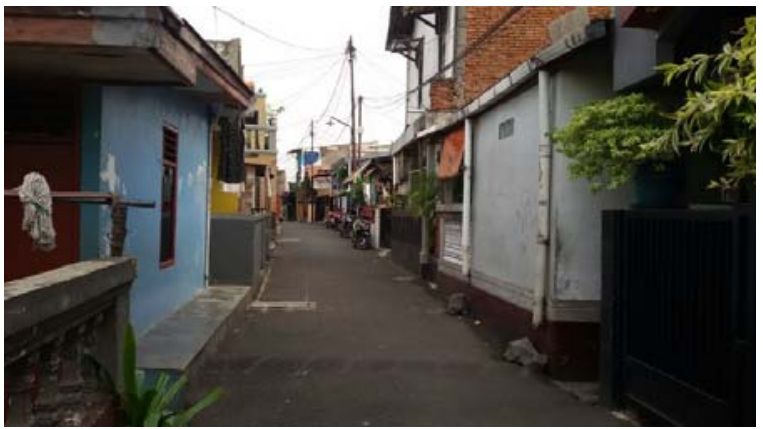

Picture 3. House of Residential Community Series RT.03 / RW.01

Population density can be seen in houses lined up along the road. The width of the neighborhood road is $1 \mathrm{Sq}$ to $1.5 \mathrm{Sq}$.

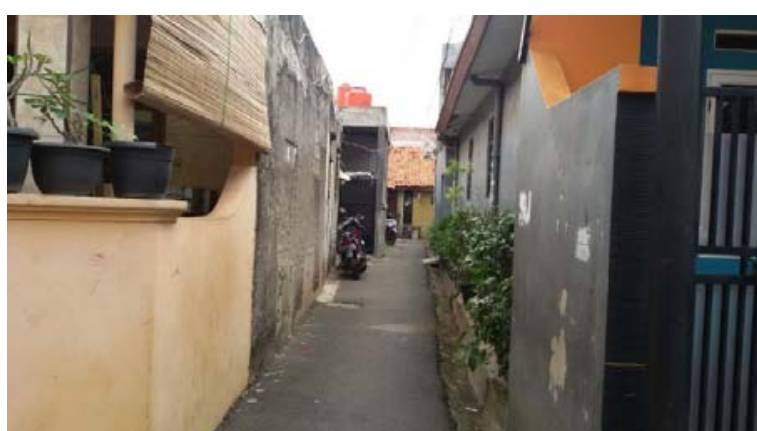

Picture 4. The transition of Function of Green Open Space into Buildings in Residential Houses in RT.03 / RW.01

The limited land in a residential house has an impact on the expansion of space requirements built on open green space. This results in the loss of greening in the neighbourhood.

\section{RESULT AND DISCUSSION}

The results of the implementation of Community Empowerment Towards Green Settlements for the Community RT.01 / RW.01 Petukangan Utara Village Pesanggrahan Subdistrict South Jakarta is increasing knowledge about creating a vertical greening system on limited land that functions as a natural air conditioner in residential homes.

Due to the lack of public knowledge about some ornamental plants that can be useful to cool the air, training was held on ornamental plants that can cool the air for the community RT.01 / RW.01 Petukangan Utara Village, Pesanggrahan District, South Jakarta. Some ornamental plants that can cool the air are:

- Lidah Mertua or Sanseviera

This plant can absorb pollution and toxins, convert $\mathrm{CO} 2$ to oxygen well at night, and cleanse the methanal in the air.

- Suplir

This plant can clean the air in the room.

- Aster Garbera Flower

This flower can produce very much oxygen and can absorb trichloroethylene which is one of the chemical compounds in the air.

- Anthurium Flower

Anthurium flowers are plants that function to absorb ammonia, formaldehyde, toluene, and xylene which is one of the chemical compounds in the air.

- $\quad$ Peace Lily Flower

Peace Lily flower can absorb formalin, benzene, and VOCs substances in the room.

- Pakis Boston

This plant can absorb toxins in the air.

- Sirih Belanda

This plant can absorb various poisons and pollution in the room, making it suitable for those who smoke at home.

- English Ivy 
English Ivy is a plant that can make the air fresher by absorbing dust through fine hairs making it suitable for people who have allergies.

- Walisongo atau Schefflera

This plant can absorb bad poisons such as benzene, formaldehyde, and toluene, so it is very good as a neutralizing air in the smoking area.

- Dendrobiumdan Phaeleonopsis or Anggrek bulan

Orchid can function to clean the air from xylene, pollutants found in glue and paint. Orchids can breathe and release oxygen at night, so they can live big in the bedroom.

- $\quad$ Krisan (Chrysanthemum)

Chrysanthemum is a plant that can clean the air because it can absorb ammonia, benzene, formaldehyde, and xylene found in the surrounding air.

- $\quad$ Lili Paris

Is an oxygen-producing plant.

By holding training on ornamental plants that can cool the air and provide souvenirs in the form of ornamental plants, the community can immediately apply them in their respective homes. In the end, the air in each house becomes cooler so that it can save energy use for artificial air conditioning.

From this training, the community is expected to develop a culture to plant ornamental plants that can cool the air in their respective homes, and transmit them to the surrounding community. Planting ornamental plants that can cool the air in each home will become a culture in the community RT.01 / RW.01 Petukangan Utara Village, Pesanggrahan District, South Jakarta.
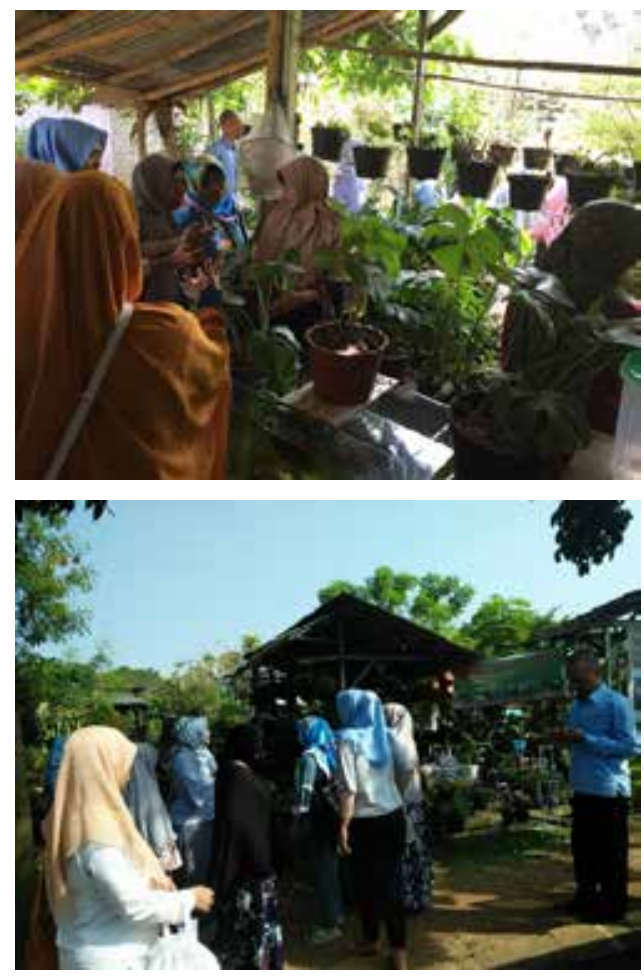

Picture 5. Air Conditioning Ornamental Plant Training in Grha Raya

Due to the limitations of open land in their respective homes, it is rarely found greening the community environment in RT.01 / RW.01 Petukangan Utara Village Pesanggrahan District, South Jakarta. Through reforestation can also be applied to limited land. Thus the training was held to make vertical garden on limited land, using potting media from reusable materials. By applying vertical garden on each residence, the air in the residence becomes cooler so that it can save energy use for artificial air conditioning. Vertical garden can use a used drink bottle media. The used bottle is cut as a media pot container, it can be mounted directly on the wall or using a rack. 

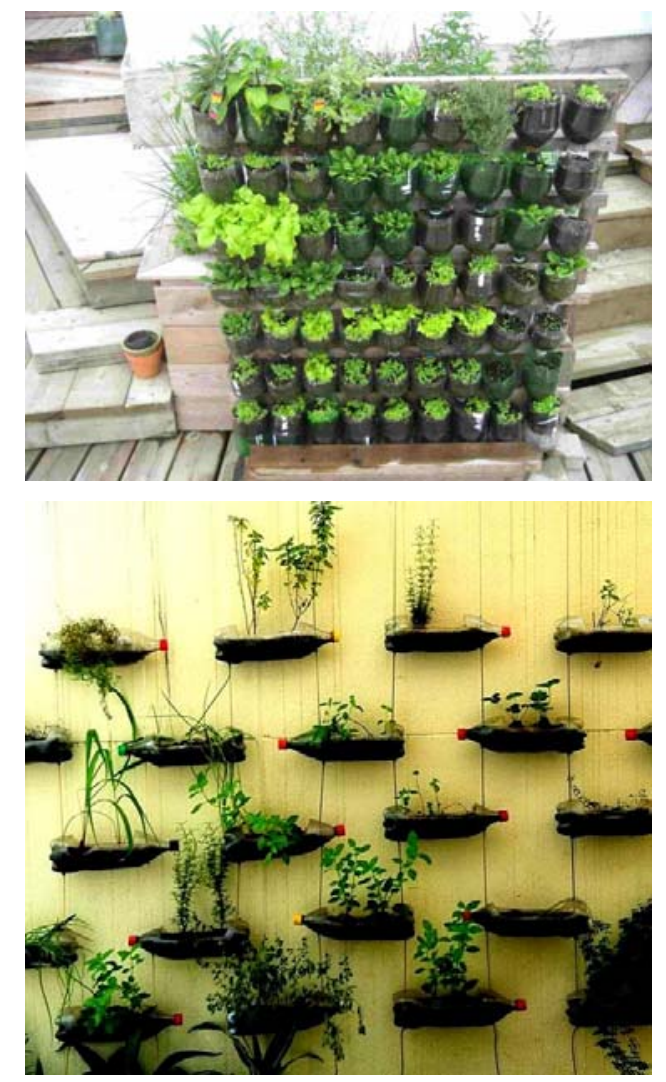

Picture 6. Examples of Plant Places from Used Bottles

After the community makes vertical garden by using potting media from materials that can be reused in their respective homes, this will spread to the surrounding community. In the end, vertical garden on limited land by utilizing materials that can be reused as a media pot will become a culture in the community RT.01 / RW.01 Petukangan Utara Village, Pesanggrahan District, South Jakarta.
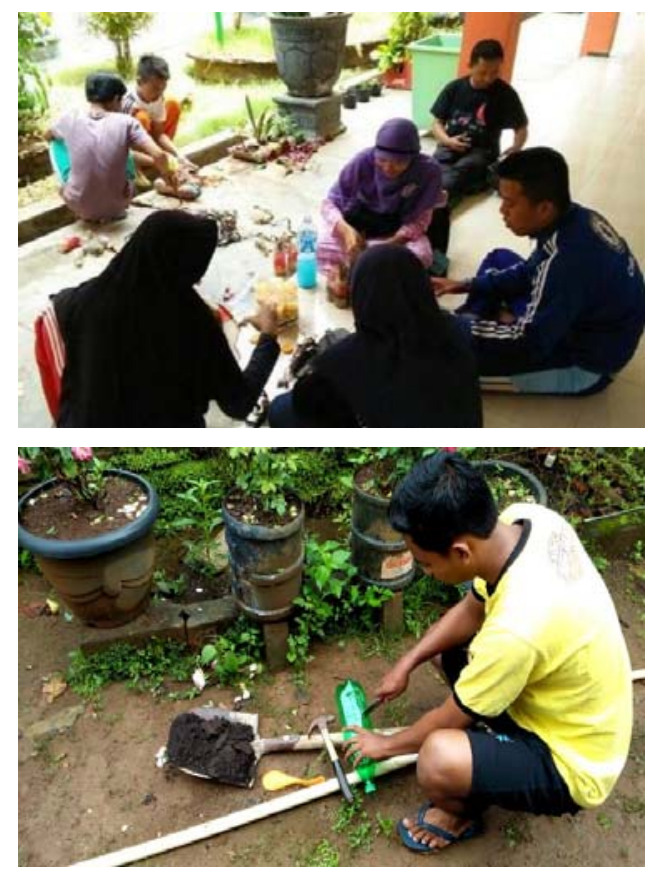

Picture 7. Training in Making Vertical Greening of Used Materials

With the Community Service Program implemented by the Architecture Study Program of Budi Luhur University through Community Empowerment Towards Green Settlements for the Community RT.01 / RW.01 Petukangan Utara Village Pesanggrahan Subdistrict, South Jakarta, the community already has knowledge about ornamental plants that are useful as conditioning air and vertical garden on limited land by utilizing reusable 
materials as potting media. With this knowledge, it is hoped that the community can begin to save energy use for artificial air conditioning in their respective homes.

Thus the community begins to implement an air conditioning system through ornamental plants that are planted vertically on the walls of the house, so the community will reduce the use of electrical energy in their respective homes. In the end, the community environment RT.01 / RW.01 Petukangan Utara Village Pesanggrahan Subdistrict South Jakarta became an environmentally friendly settlement.

\section{CONCLUSION}

RT.03 / RW.01 Petukangan Utara Village Pesanggrahan Subdistrict South Jakarta is one of the densely populated settlements in DKI Jakarta. This area is categorized as included in densely populated settlements due to the density of residents and the density of buildings in the settlement.

The limited land in residential areas is due to the maximization of land area used for buildings, resulting in violations of the availability of Green Open Space in almost all residences. So that the air in the settlement becomes unhealthy.

By training ornamental plants that can cool the air and vertical garden on limited land by using materials that can be reused for potting media, the community RT.03 / RW.01 Petukangan Utara Village Pesanggrahan District, South Jakarta can cool the air in their respective homes, to create a green settlement in the area.

\section{REFERENCES}

Anggraeni Dyah, 2017. Pendampingan Pembuatan Rumah Pupuk Kompos Di Kampung Belakang Kamal Jakarta Barat. Semin. Nas. Has. Pengabdi. Kpd. Masy.

Anggraeni Dyah, 2018. Science And Technology For Communities Towards Recycling Villages On Rt.01 \& Rt.03 / Rw.01 In Petukangan Utara, Pesanggrahan, Jakarta Selatan. ICCD 1.

Husein abbualrejal, 2017. Green Building Toward Construction Sustainability : Energy.

Pourpeikari Haris, M., 2017. Evaluating metropolitan spatial development: a method for identifying settlement types and depicting growth patterns. Reg. Stud. Reg. Sci. 4.

Ragheb, A., El-shimy, H., Ragheb, G., 2016. Green Architecture : A Concept Of Sustainability 216, 778-787. 